\title{
The Legal Framework of the EAC
}

\author{
Elvis Mbembe Binda
}

\section{1 \\ Attribution, Scope and Nature of Competence}

The competence of the East African Community (EAC) as an intergovernmental organization is not stated expressis verbis in the Treaty for the Establishment of the East African Community (the Treaty). Unlike the EU where the powers of the supranational organization were clearly defined from the onset as to be distinguished from the competence of the Member States, in the EAC the situation is quite blurred. ${ }^{1}$ In fact, the competence of the EAC can rather be implied from the objectives of the Community as broadly set in Article 5 of the Treaty.

According to Article 5(1), the objective of the Community is to "develop policies and programmes aimed at widening and deepening co-operation among the Partner States in political, economic, social and cultural fields, research and technology, defense, security and legal and judicial affairs, for their mutual benefit". Obviously, this is a very broad objective that embraces all the imaginable aspects of Community life. However, the Community's competence is limited to enhancing cooperation in specific areas that the Partner States agreed to undertake in common. ${ }^{2}$ As far as these fields are concerned, it can be considered that a portion of competence has been conferred by the Partner States to the EAC, which is henceforth entitled to act within the limits of the powers conferred upon to it. ${ }^{3}$ This includes making policies, enacting legislations, making regulations, issuing directives, taking decisions, making recommendations, or giving opinions to further the objectives of the community.

Pursuant to Article 8(1)(b) the Partner States have an obligation to work in close collaboration with the EAC institutions in the coordination of

* The author gratefully recognizes that paragraph 3.3, of this chapter was written by Professor K. Gastorn.

1 See the clear listing under Art. 3 of the Treaty of Rome (1957) and its modification in subsequent EU Treaties, including the current Articles $4-6$ TFEU. For a further overview see EU Chapter 3.

2 See their list in the next section.

3 Art. 9(4) of the EAC Treaty.

(C) ELVIS MBEMBE BINDA, 2017 | DOI 10.1163/9789004322073_006

This is an open access chapter distributed under the terms of the CC-BY-NC License. 
their economic and other policies in order to achieve the objectives of the Community. ${ }^{4}$ This provision can be construed as enabling a kind of concurrent competence between the Partner States and EAC. Therefore, this means the conferred competence to the Community on some matters does not imply that the Partner States have automatically lost their authority to act on the same matters. Actually, the Partner States are entitled to continue making and applying their own policies and laws - even on matters under the competence of the $\mathrm{EAC}$ - as long as the latter has not yet made a common rule applicable to all of the Partner States. In other words, the competence of the Partner States ends where that of the Community start being exercised. ${ }^{5}$

Looking at the EU competence typology, ${ }^{6}$ it can be inferred from various provisions that the EAC Treaty has consecrated a general regime of shared competence between the Community and the Partner States.

\subsection{Main Competences of the EAC}

The Treaty does not contain a single article that exhaustively lists the areas or powers that the Partner States intend to confer to the Community. The wording of the Treaty is rather very subtle and requires attention to find out whether a specific area of competence has been transferred to the EAC. In fact, Treaty provisions generally impose obligations directly on the Partner States in terms such as "the Partner States shall..." and "the Partner states agree...", which confirms that the EAC is a Partner States-led organization in accordance with its intergovernmentalist integration approach. However, some paragraphs are inserted under those articles to legitimize the intervention of EAC institutions either by reserving to them a fair amount of latitude to determine the course of a certain action or by entrusting them with the power to act with immediate effect, with effect on a certain specified time or as soon as certain requirements are met. ${ }^{7}$ It has been suggested that whenever a provision contains such a paragraph, it should be construed as conferring competence to the Community. ${ }^{8}$

4 Art. 4(1)(b) of the EAC Treaty.

5 A.G. Toth, 'The Principle of Subsidiarity in the Maastricht Treaty', (1992) 29 Common Market Law Review 1079, p. 1080. Compare in this regard also the discussion in EU Chapter 3 on the nature of shared competences in the $\mathrm{EU}$.

6 See Art. 2 of the Treaty on the Functioning of the European Union (TFEU).

7 See for instance arts. 75(2), (3) and (4); 76(2) and (3); 8o(2); 84(1); 85; 86; etc.

8 A.G. Toth, op. cit., p. 1081. 
In line with this, a careful reading of various Treaty provisions suggests that the Partner States intended to confer powers to the Community in the following areas:

(i) Trade liberalization and development, including the establishment of a Customs Union and a common market (Articles.

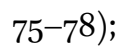

(ii) Investment and industrial development (Articles. 79-80);

(iii) Standardization, quality assurance, metrology and testing (Article. 81);

(iv) Monetary and financial matters, including the free movement of capital (Articles. 82-88);

(v) Infrastructure and services (Articles. 89-101);

(vi) Development of human resources, science and technology (Articles. 102-103);

(vii) Free movement of persons, labor, services, right of establishment and residence (Article. 104)

(viii) Agriculture and food security (Articles. 105-110)

(ix) Environment and natural resources management (Articles. 111$114)$;

(x) Tourism and wildlife management (Articles. 115-116);

(xi) Health, social and cultural activities (Articles. 117-120)

(xii) Enhancing the role of women in socio-economic development (Article. 121)

(xiii) Political matters (Articles. 123-125);

(xiv) Legal and judicial affairs (Article. 126)

This list is not exhaustive as, pursuant to Article 131, the Partner States may decide to extend their scope of co-operation to other fields. Besides, in addition to the competence in areas mentioned in these general provisions, it should be understood that the EAC also has implied competences in any other domain not listed above as long as such competence is necessary to perform the activities under these areas in order to achieve the Treaty objectives.

\subsection{The Principle of Variable Geometry and Enhanced Co-operation}

As an operational principle of the Community, the principle of variable geometry is the principle of flexibility that allows for progression in co-operation among a sub-group of Partner States in a larger integration scheme in a variety 
of areas and at different speeds. ${ }^{9}$ The principle of variable geometry rests on the rationale that in any given community some members are able to integrate more than others in a variety of areas and at different speeds. It is not a rule of exclusion, it simply allows Partner States to jointly agree on issues but implement them at different speeds.

The concept of variable geometry is also known as the principle of flexibility, differentiated integration, enhanced co-operation, Europe à la carte, concentric circles, and multi-speed Europe. ${ }^{10}$ That means, the concept of enhanced cooperation as practiced in the $\mathrm{EU}$ where a limited number of EU members may cooperate in an area without other members is associated with the concept of variable geometry in the context of the EAC.

In the context of the EAC, the principle of variable geometry is not developed. However, the East African Court of Justice has opined that the principle of variable geometry is in harmony with the requirement for consensus in Council decision-making. Adding that, the principle is a strategy of implementation of Community decisions and not a decision making tool itself and it therefore guides the integration process. ${ }^{11}$

As much as the principle of variable geometry is viewed as a necessary means of enabling those ready to proceed, and hoping the remaining States follow later, it has the danger of creating a small community within a community that might ultimately endanger the cohesion of the larger community. The EACJ accordingly advised that the principle of variable geometry should be resorted to as an exception, not as a rule since institutionalized flexibility might lead to a breakup of the Community or its transformation into a mere free trade area. ${ }^{12}$ It is advised that in a young community like the EAC, the principle of legal unity should be stressed instead of variable geometry. ${ }^{13}$

9 Arts. 1(1) and 7(1)(e) of the EAC Treaty.

10 See http://www.euro-know.org/europages/dictionary/v.html (30 Sept 2013); Bomberg, E., et al., The European Union: How does it work? (Oup 2012), p. 163 .

11 In the Matter of a Request by the Council of Ministers of the East African Community for an Advisory Opinion, Application No. 1 of 2008, In the East African Court of Justice at Arusha First Instance Division [Coram: Johnston Busingye, PJ; Mary Stella Arach-Amoko, DPJ; John Mkwawa, J; Jean-Bosco Butasi, J; Benjamin Patrick Kubo, J].

12 See http://www.euro-know.org/europages/dictionary/v.html) (30 Sept 2013); In the Matter of a Request by the Council of Ministers of the East African Community for an Advisory Opinion, Application No. 1 of 2008, In the East African Court of Justice at Arusha First Instance Division [Coram: Johnston Busingye, PJ; Mary Stella Arach-Amoko, DPJ; John Mkwawa, J; Jean-Bosco Butasi, J; Benjamin Patrick Kubo, J]; M.J. Maalim, The United Republic of Tanzania in the East African Community: Legal Challenges in Integrating Zanzibar, (PhD Thesis, University of Dar es Salaam, 2013), p. 56.

13 R. McAllister, European Union: An Historical and Political Survey (Routledge 2010), p. 91. 
According to Henry Kibet Mutai, the principle of variable geometry was incorporated in the EAC Treaty primarily to allay the concerns of Tanzania and Uganda, which feared that, given their relatively low levels of development, their economies ran the risk of being swamped by Kenyan goods if they were obliged to liberalize at the same rate..$^{14}$

The design of variable geometry as a negotiation strategy and as a strategy of implementation of agreed activities is complex and difficult. The concept of variable geometry suits a larger group of countries among which a subset is initially willing to enter an agreement. ${ }^{15}$ It first appeared in EU Treaties and has later arisen in other negotiations particularly in the World Trade Organization as a possible way of breaking the impasse in failed negotiations, such as the GATTs opt-in agreements on Technical Barriers and Government Procurement. ${ }^{16}$

In the EU, variable geometry started with the 1990 Schengen Convention relating to the free movement of person among the Schengen States where Ireland and the UK were not willing to remove controls on the intra-EU movement of non-EU nationals. ${ }^{17}$ Then again in 1991 where 11 Member States of the EU signed the Social Policy Agreement relating to employment and working conditions, but the UK opted out. In 1992, the European Economic and Monetary Union (EMU) adopted the common currency, the euro, and common monetary policy under the European Central Bank. The UK, Ireland and Denmark immediately refused to sign and thereby retained their own currencies, with Ireland joining at a later date. ${ }^{18}$

In the $\mathrm{EU}$, the principle of variable geometry was first formalized in the 1997 Treaty of Amsterdam, then christened as 'closer co-operation', largely in response to the UK's and Denmark's opt-outs on European Monetary Union, the UK's and Ireland's exemptions from the Schengen Agreement and Denmark's

14 As quoted in J.V. Mwapachu, Challenging the Frontiers of African Integration: The Dynamics of Policies, Politics and Transformation in the East African Community, (E\&D Vision Publishing, Dar es Salaam 2012), p. 365.

15 P. Lloyd, 'The Variable Geometry Approach to International Economic Integration', University of Melbourne, p. 51. See http://journals.usb.ac.ir/Business/en-us/Articles/ Article_172/ (accessed 15 November 2013).

16 P. Lloyd, op. cit., p. 56 .

17 C. Barnard, The Substantive Law of the EU: The Four Freedoms, (oup 2010), pp. 524-527; Lloyd, Peter, 'The Variable Geometry Approach to International Economic Integration', supra, pp. 53-54.

18 P. Lloyd, op. cit., p. 54. See also EU Chapter 13 on the development of EMU in the EU, and the problems this has created. 
opt-out on anything to do with a common EU defence policy. ${ }^{19}$ These opt-outs had already created de facto variable geometry.

Today, variable geometry agreements and the 'acquis communautaire' are the two main tracks of greater integration within the $\mathrm{EU}$. The 'acquis communautaire' refers to E U's total body of legislation or what has so far been achieved by the EU. ${ }^{20}$ However, the acts adopted in the framework of the variable geometry bind only participating Member States and they do not in formal terms constitute part of the acquis that has to be accepted by candidate states for accession to the EU. According to Peter Lloyd, variable geometry has the following features. ${ }^{21}$ First, it is an opt-in agreement devised by a proper subset of a larger group of countries. It is therefore an opt-in strategy as opposed to à la carte practices of opting out. ${ }^{22}$ Second, its benefits are restricted to the subset of countries. Third, it is a union of temporary steps towards the eventual inclusion of all members into the negotiated arrangements.

In the EAC, this principle found practical application when Kenya, Rwanda and Uganda decided in 2013 to fast-track some integration projects such as the establishment of a single customs territory, a single tourist visa and the use of national identity card as travel documents for their citizens to cross their mutual borders. ${ }^{23}$ Tanzania and Burundi were not ready to be involved. Therefore, based on the principle of variable geometry, Kenya, Rwanda and Uganda launched the projects and left it open to the discretion of Burundi and Tanzania to join whenever they deem appropriate.

19 (http://www.euro-know.org/europages/dictionary/v.html) (30 Sept 2013).

20 S. Hargreaves, EU Law, (oup 2009), p. 18. Also see Y. Usui, "Constructing an East Asian Acquis", in Nkamura, Tamio (ed), East Asian Regionalism from a Legal Perspective: Current features and a vision for the future, (Routledge 2009), pp. 231-243.

21 P. Lloyd, op. cit., pp. 58 and 63.

22 J. Janning, 'European Democracy and Variable Geometry. How a multi-speed Europe complicates the Union's democratic legitimacy', (2013), p. 2. See https://ip-journal.dgap.org/en/ ip-journal/topics/european-democracy-and-variable-geometry (accessed 25 December 2013).

23 See G. Ajumbo, 'Is Variable Geometry Leading to the Freagmentation of Regional Integration in East Africa?', available on http://www.afdb.org/en/blogs/integrating-africa/ post/is-variable-geometry-leading-to-the-fragmentation-of-regional-integration-in-eastafrica-12524/ last access on 15 November 2016. 


\subsection{Legal Instruments}

\subsubsection{Treaty and Protocols}

The EAC legal landscape consists of the Treaty and protocols concluded by the Partner States to enhance their cooperation in agreed areas. In principle, each protocol spells out its objectives, scope and any institutional framework needed for cooperation and integration. According to Article $15^{1}$ of the Treaty, each protocol becomes an integral part of the Treaty after signature and ratification following the approval by the Summit on the recommendation of the Council.

So far, more than a dozen protocols have been ratified and are in force. ${ }^{24}$ Among them, three deserve to be mentioned given their paramount significance for the regional integration process in the EAC. The first protocol is the Protocol on the Establishment of the East African Customs Union which entered into force in 2005 with the main aim of eliminating internal tariffs and other charges of equivalent effect as well as non-tariff barriers in order to smoothen the free movement of goods between the Partner States. The second is the Protocol on the Establishment of the East African Common Market in force since 2010. ${ }^{25}$ This Protocol focuses on the free movement of labor, services and capital while fostering the freedom of establishment and that of residence for EAC Partner States' nationals. The third protocol worth mentioning is the Protocol on the Establishment of the East African Community Monetary Union. This Protocol entered into force in 2015 after its ratification by all the Partner States with the objective to "promote and maintain monetary and financial stability aimed at facilitating economic integration to attain sustainable growth and development of the Community". 26

24 Inter alia can be mentioned Protocol on the Decision-Making by the Council of the East African Community [2001]; Protocol on the Establishment of the East African Kiswahili Commission [2007]; the Protocol on Combatting drug trafficking in the East African Community [2001]; Protocol on Standardization, Quality Assurance, Metrology and Testing [2001]; Protocol on the Establishment of the East African Civil Aviation Safety and Security Oversight Agency [1999]; Protocol on the Establishment of the East African Science and Technology Commission [2008]; Protocol on Peace and Security [2013]; Protocol on the Establishment of the East African Health Research Commission [2008]; Protocol for the Sustainable Development of Lake Victoria Bassin [2003]; Protocol on Environment and Natural Resources Management [2006]; etc.

25 See also Chapter 9, 10, 11 and 12 for a more detailed discussion of these Protocols.

26 Art. 3 of EAC Monetary Union Protocol as well as Chapter 13. 
Each of these protocols embodies, respectively and successively, the attainment of the first three key stages of the EAC regional integration process, i.e. customs union, common market and monetary union as affirmed in paragraph fifteen of the preamble to the Treaty. The Protocol on the Establishment of a Political Federation, the ultimate stage of EAC regional integration, is still in an embryonic draft stage.

Acts and regulations are enacted for the implementation of Treaty protocols. In relation to the protocols mentioned above, one could name the East African Custom Management Act (2004) and the East African Community Customs Union (Rules of Origin) Rules as amended to date, and the six annexes ${ }^{27}$ to the Common Market Protocol as some of the acts and regulations in force in the EAC.

\subsubsection{General Principles}

The Treaty makes a distinction between fundamental principles of the Community and its operational principles. ${ }^{28}$ On the one hand, according to Article 6, the achievement of the objectives of EAC regional integration is governed by fundamental principles of (a) mutual trust, political will and sovereign equality; (b) peaceful co-existence and good neighborliness; (c) peaceful settlement of disputes; good governance including adherence to the principles of democracy, the rule of law, accountability, transparency, social justice, equal opportunities, gender equality, as well as the recognition, promotion and protection of human and peoples rights in accordance with the provisions of the African Charter on Human and Peoples' Rights; (e) equitable distribution of benefits; and (f) cooperation for mutual benefit.

On the other hand, Article 7 provides for operational principles that must be observed for the practical achievement of the objectives of the Community. These are principles of (a) people-centered and market-driven cooperation, (b) the provision by the Partner States of an adequate and appropriate enabling environment, such as conducive policies and basic infrastructure;

27 Annex 1: The East African Community Common Market (Free Movement of Persons) Regulations; Annex 2: The East African Community Common Market (Free Movement of Workers) Regulations; Annex III: The East African Community Common Market (Right of Establishment) Regulations; Annex IV: The East African Community Common Market (Right of Residence) Regulations; Annex v: The East African Community Common Market Schedule of Commitments on the Progressive Liberalization of Services; and Annex vi: The East African Community Common Market Schedule on the Removal of Restrictions on the Free Movement of Capital.

See for a detailed discussion in this point also Chapter 6. 
(c) the establishment of an export oriented economy for the Partner States in which there shall be free movement of goods, persons, labor, services, capital, information and technology; (d) the principle of subsidiarity which emphasizes on multi-level participation and the involvement of a wide range of stake-holders in the process of integration; the principle of variable geometry allowing for progression in cooperation among groups within the community for wider integration schemes in various fields and at different speeds; (f) the equitable distribution of benefits accruing or to be derived from the operations of the Community and measures to address economic imbalances that may arise from such operations; the principle of complementarity; and (h) the principle of asymmetry. In addition to these principles, good governance also appears as one of the operational principles of the EAC.

The treaty-makers found it judicious to erect two principles that at the same time form fundamental and operational principles of the Community. These are the principle of equitable distribution of the benefits of the Community and the principle of good governance. ${ }^{29}$ This is not by chance. To understand the reason for this choice, one may want to refer to paragraph 4 of the preamble to the Treaty where the "continued disproportionate sharing of benefits of the Community among the Partner States" and the "lack of adequate policies to address this situation" are deplored as some of the main reasons that caused the collapse of the former EAC in 1977 .

In fact, right after independence, Uganda and Tanzania already started complaining that the British system had favored Kenya which became more industrialized than her two other Partner States. This allegedly caused serious trade imbalances whose manifestation was that Uganda and Tanzania imported from Kenya more than they could export. They contended that this situation was actually fostered by the customs union which became fully-fledged among them in 1940. As a result of the customs union's common external tariff, it was difficult for products from third countries to penetrate the Community market. Hence, Uganda and Tanzania had to import quasi-exclusively from Kenya. This situation contributed a lot to the economic development of Kenya, but to the detriment of the other two EAC countries. According to Uganda and Kenya, this was one of the materializations of the inequitable sharing of the benefits of the Community. ${ }^{30}$ The Kampala agreement and the treaty establishing the former EAC attempted to address this issue of inequitable distribution of the benefits of the community in 1964 and in 1967 , respectively. However,

\footnotetext{
29 See Arts. 6(e) and $7(\mathrm{f})$ for the principle of equitable distribution of the benefits; and arts. $6(\mathrm{~d})$ and $7(2)$ for the principle of good governance.

$30 \quad$ See on this point also further Chapters 9 and 13.
} 
this was in vain. It is probably to highlight the fatality of this issue in order to urge the Partner States to find an effective solution that Treaty-makers resolved to make the "equitable distribution of the benefits of the Community" one of its dualist general principles under Articles 6 and 7 .

On the other hand, good governance as a general principle is one of the pillars that supports the entire EAC architecture. In this sense, the EACJ held that the principle of good governance has to be observed as it is "foundational, core and indispensable to the success of the integration agenda". ${ }^{31}$ Good governance acts as the steering principle to ensure that both the Partner States, and EAC organs and institutions are effectively and efficiently converging towards the achievement of the integration objectives.

Apart from the principle of variable geometry and that of good governance which have been addressed by the EACJ, the scope and the practical meaning of other general principles enshrined in the Treaty are not yet ascertained. While the concrete meaning of the principle of variable geometry was asked to the Court by the Council in order to break a deadlock in which its decisionmaking seemed to be trapped, ${ }^{32}$ the scope and the practical meaning of the principle of good governance was rather an outcome of EAC citizens' activism.

In fact, for some reasons, the Treaty-makers subjected the human rights jurisdiction of the EACJ to the adoption of an ad hoc protocol. ${ }^{33}$ As this protocol is still awaited, pursuant to Article 30 of the Treaty that gives quality to "any person who is resident in a Partner State" to refer a case on the unlawfulness of any Partner State's act, regulation, directive, decision or action to the EACJ, EAC nationals resorted to Article 6(d) that provides for good governance as a fundamental principle of the Community to bypass the human rights jurisdictional confinement imposed on the EACJ. According to Article 6 (d) good governance is defined as encompassing "adherence to the principles of... rule of law ... as well as the recognition, promotion and protection of human and peoples rights..." Therefore, it was quite straightforward for applicants to claim that human rights violations by a Partner State form an infringement of Articles 6(d) and 7(2) of the Treaty. The EACJ did not hesitate to uphold that while it could not assume jurisdiction to "adjudicate human rights disputes, [the Court] will not abdicate from exercising its jurisdiction of the interpretation under Article 27(1) merely because the Reference includes

31 Reference No. 5 of 2011, Samuel Mukira Mohochiv. The Attorney General of the Republic of Uganda, Judgment, 17 May 2013, para 36.

See Application No. 1 of 2008, Advisory Opinion, 13 September 2008. For more details on the principle of variable geometry in the EAC Treaty, see supra (section 3.3.). 
allegations of human rights violations" ${ }^{34}$ Hence the Court concluded that the principle of good governance in Articles 6(d) and 7(2) of the Treaty contains a clear intention of the Treat-makers to safeguard individuals against arbitrary governance and ill treatment by totalitarian leader, or mob rule.

This ruling paved the way for several other human rights cases based on the violation of the principle of good governance. ${ }^{35}$ Accordingly, good governance has become the most used general principle of the Treaty. This contributed a lot to the clarification of the definition of good governance and to the framing of its substantial scope.

\subsubsection{Regulations, Directives, Decisions, Recommendations and Opinions}

Article 8(2)(b) provides for the obligation of the Partner States to confer upon Community legislation, regulations and directives the force of law within their territories. However, the Treaty does not define what the Community's regulations, directives or decisions are; nor does it provide a clear hierarchy or procedural differences between them. Therefore, arguing on the difference of their respective binding force could be difficult. Indeed, Article 16 of the Treaty that touches this issue of the binding force of the Community's regulations, directives, decisions, recommendations, and opinions rather focuses on those taken by the Council, by stipulating that they are binding on the Partner States, on all organs and institutions of the Community other than the Summit, the Court and the Assembly within their jurisdictions. This is understandable as the Council is the policy organ of the Community. ${ }^{36}$ In addition, pursuant to Article 11(5) of the Treaty the Summit can delegate some of the powers (including legislative powers) conferred to it to the Council. However, this does not

Reference No. 1 of 2007, James Katabaziv. Secretary General of the East African Community and the Attorney General of the Republic of Uganda, Judgment of 1 November 2007, para. 41 [emphasis supplied].

35 See for instance: Reference No. 1 of 2010, Honorable Sitenda Sibalu v. the Secretary of the EAC, Attorney General of Uganda, Honorable Sam Njuba, and the Electoral Commission of Uganda, Judgment of 30 June 2011; Reference No. 7 of 2010, Mary Ariviza and Okotch Mondoh v. Attorney of Kenya and Secretary General of the East African Community, Judgment of 30 November 2011; Reference No. 30 of 2010, Independent Medico Legal Unit v. Attorney General of Kenya, Judgment of 1 March 2013; Reference 4 of 2011, Omar Awadh and Six Others v. Attorney General of Kenya and Attorney General of Uganda, Judgment of 15 April 2013; and Reference No. 8 of 2010, Plaxeda Rugumba v. Secretary General of the EAC and Attorney General of Rwanda, Judgment of 1st December 2011; Reference No. 9 of 2012, East African Center for Trade Policy and Law v. Secretary General of the EAC, Judgment of 9 th May 2013 .

36 Art. 14(1) of the Treaty. 
answer the question of the difference in both the nature and the binding force of EAC acts. Even a look at the EAC Protocol on the Council's decision-making does not provide the expected distinction.

Therefore, it can be noticed that the concern of the Treaty-makers was more to establish a hierarchy between the acts of the Community and those of the Partner States than to make a clear internal distinction between Community acts. This is clearly highlighted in Article 8(4) that provides for the precedence of Community laws over the similar ones of the Partner States. It means that in case of conflict EAC legislation, regulations, and directives, recommendations and opinions should take precedence over any Partner States' national acts of a similar effect. ${ }^{37}$

\subsection{Legislation and Decision-making}

This section addresses the legislative process of bills by the East African Legislative Assembly, the law-making institution of the EAC, and sheds light on the Council's decision-making.

\subsubsection{Legislative Procedures}

The Treaty confers power to initiate legislation to both the Council of Ministers and the East African Legislative Assembly (the Assembly). This implies a dichotomist approach to the EAC legislative process. On the one hand, there is the Council Bill initiated by the Council ${ }^{38}$ and directly introduced to the Assembly for the first reading. On the other hand, there is the Private Member's Bill that can be initiated by any member of the Assembly. 39

A Private Member's Bill is introduced by way of motion to which is attached the proposed draft of the bill. The Counsel to the Community has the obligation to provide reasonable professional assistance in drafting the bill to any Assembly member who intends to move a Private Member's Bill before it can be compiled by the clerk in order to be attached to the motion. ${ }^{40}$ In case the motion is carried, the clerk of the Assembly has the responsibility to print and publish the concerned bill in the Gazette, ${ }^{41}$ as it is a rule that every bill has to be printed and published in the Gazette before its introduction to

$37 \quad$ See further on this issue Chapter 4.

38 See Art. 14(3)(b).

39 See Art. 59(1) of the Treaty and Rule. 64(1) of EALA Procedure.

40 Rule $64(2),(3)$ and (4) of the EALA Procedure.

41 Rule 64(6) EALA Procedure. 
the Assembly. ${ }^{42}$ It is worth mentioning that although Assembly members are entitled to introduce a Private Member's Bill, such a bill cannot be proceeded if its purpose would amount to the imposition of any financial charge upon any Community's fund, either directly or indirectly. ${ }^{43}$ Moreover, a bill, motion or amendment that is likely to result in the derogation from the enjoyment of human rights cannot be introduced before the Assembly. ${ }^{44}$

After introduction, every bill (either Council Bill or Private Member's Bill) has to be read three times before being passed. The first reading is a kind of introduction of the bill to the Assembly. It consists of an aloud reading of the short title of the bill by the clerk. Afterwards, the bill is referred to the Committee which should analyze it and present its report to the Assembly within 90 days. This deadline can be extended for an extra period of 30 days with the permission of the Assembly if the Committee fails to complete its report within the given period. ${ }^{45}$ The work of the Committee is not ceremonial but rather is very critical as it is at this stage that the relevance of the bill is assessed. In order for a bill to progress, the Committee needs to be convinced that there is a positive balance between the advantages and the disadvantages of the bill. In case the Committee needs an external expertise to make its mind, it may be allowed to appoint experts for advice. ${ }^{46}$ The Committee's assignment also involves conducting widespread consultations with members of the Council of Ministers, representatives of Partner States' institutions related to the matter of the bill, national parliaments, and the citizens who are basically the final beneficiaries of EAC acts. ${ }^{47}$

If after this scrutiny process the Committee finds that relevant amendments should be done to the bill, it may recommend so. Furthermore, the Committee,

42 Rule 61 EALA Procedure. Exception to the publication rule is when a given bill is declared to be of an urgent nature by the Assembly on a motion by any EALA member. In this case the bill may be introduced without publication and such a bill may be taken through all the legislative stages in one day (Art. 62 EALA Procedure).

43 Art. 59(2) of the Treaty.

44 Rule 63 of the EALA Procedure. This is a strong token for the protection of human rights by the EALA, and the EAC at large.

45 Rule 66(6) of the EaLA Procedure.

46 EAC, 'Report of the Capacity Building Workshop for the Committee on General Purpose: "The Legislative process of Bills: From Initiation, enactment to oversight on enacted law", Nairobi, 6-9 August 2014, p. 3 online at http://www.eala.org/new/index.php/key-docu ments/reports/5oo-capacity-building-workshop-for-the-eala-committee-on-generalpurpose?path=, accessed on 15 November 2016.

47 Ibid. Public consultation occurs through public hearing workshops that the committee has to undertake in all Partner States. 
through its chairperson, has competence to review and accept proposals for correction of blatant misprints and punctuation errors in the bill without any formal request from a member of the Assembly. ${ }^{48}$

When the Committee is satisfied of the bill's relevance, it is submitted to the second reading upon the request of the Council chairperson or the Assembly member who initiated the bill, depending on whether it is a Council Bill or a Private Member's Bill. The report of the Committee is presented to the whole Assembly by the chairperson of the Committee. This opens the bill to debate on its merits and principles, which will have the consequence of sending the bill to its next level, the Committee of the Whole House. ${ }^{49}$ This Committee is constituted of all the members of Assembly and is chaired by the Speaker who acts for this specific purpose as the chairperson of the Committee of the Whole House. At this stage, the Assembly proceeds with an article-by-article review and adoption of the bill. When amendments are suggested, they are debated and eventually adopted.

At the end of the second reading, the bill is submitted with the permission of the Speaker to the Assembly for the third reading, either immediately or on a day decided by the Speaker.

However, even after a bill is set for the third reading, any member can request that a given provision be deleted, amended or added. ${ }^{50}$ However, this must be done before the third reading is introduced. In case a bill is suggested for a partial or whole amendment, it should go back through the procedure of the Committee of the Whole House as described above until the bill is adopted. ${ }^{51}$ The third reading constitutes the adoption of the bill by the Assembly, ${ }^{52}$ and indicates that the bill is ready to be sent to each of the EAC Heads of States for their assent.

A bill becomes an act of the Community when it receives the assent of all the Heads of State of the Community. In case one or more Heads of States

48 Rule 67(3) of Eala Procedure.

49 Rule 69 of Eala Procedure.

50 Rule 72(1) of EALA Procedure.

51 Rule $72(3)$ of EALA Procedure.

$5^{2}$ It is noteworthy that the EALA decides on all questions by a majority of votes of the elected members present and voting on the basis of one person one vote. The speaker or the chairperson of committee does have neither an original nor a casting vote (Rule 54 of EALA Procedure). Thus, if on an issue votes of the members are equally divided, the motion should be lost (art. 58(4) of the Treaty). Ex-officio members by virtue of article $48(1)$ (b) of the treaty (minister, assistant minister in charge of EAC, the secretary general and the counsel to the community) do not hold a voting right in the deliberations of the EALA. See Art. 58(2) of the Treaty. 
withhold their assent to a bill, a notification is sent to the Speaker who informs the Assembly about this occurrence. The returned bill and the reason why assent was withheld are laid on the table of the Assembly by the member who initiated that bill for further referral to the relevant Committee in order to undergo scrutiny of the clauses objected by the Heads of State. ${ }^{53}$

\subsubsection{Decision-making and Delegation of Powers}

The Council is the policy organ of the EAC. ${ }^{54}$ For this reason, this section is mainly dedicated to the decision-making by this organ. According to Article 15(4) of the Treaty, "the decisions of the Council shall be by consensus", subject to a Protocol on the Decision-making. ${ }^{55}$ However, the provisions of this Protocol suggest that consensus is just one of the two modes on which Council decisions can be made. In fact, Article 2 of this Protocol exhaustively lists matters that require consensus. It includes granting observer status to an intergovernmental organization or civil society organization; making the financial rules and regulations of the Community; submission of the annual budget to the Assembly; approval of the expenditures of the community; establishment of any sectoral council or committee under the Treaty; submission of Bills to the Assembly; decision policy-making for the efficient and harmonious functioning and development of the community; and decisions on what should be recommended to the Summit on matters such as the amendment of the Treaty; the approval or amendment of any protocol; the admission of new members, the granting of observer status to foreign countries; the imposition of sanctions; the suspension of a member; the transformation into a political federation; and the expansion of areas of cooperation.

All other decisions are taken by simple majority. ${ }^{56}$ This provision may raise the question of knowing whether simple majority should also be used when the Council is acting pursuant to powers delegated to it by the Summit. As a reminder, Article 11(5) and (6) of the Treaty stipulates the possibility of power delegation from the Summit to the Council or to the Secretary General. The Summit may delegate any of its Treaty-conferred powers except the giving

53 Rule 73(5) of EALA Procedure. In this case, the procedure to be followed is the same as the one prescribed by art. 72 applicable in case a member of the EALA suggests the amendment of a bill after the second reading but before the third reading.

54 Art. 14(1) of the Treaty.

55 See on the vital importance of the shift towards Qualified Majority voting in EU decisionmaking further Eu Chapters 2 and 3 .

56 Art. 2(2) of the Protocol on the Decision Making by the Council of the East African Community [2001]. 
of general directions and impetus; the appointment of judges to the EACJ, the admission of new members and granting of observer status to foreign countries; and assent of bills. ${ }^{57}$ Given that the decisions of the Summit are made by consensus, ${ }^{58}$ and yet the Protocol on the decision-making of the Council does not mention the exercise of summit powers by the Council among the matters to be decided upon by consensus, one may wonder whether such decisions are also made by simple majority pursuant to Article 2(2) of this protocol on the decision-making of the Council. Obviously, this does not seem to be the intention of the Treaty-makers especially that this would eventually have a consequence of turning this delegation into an alteration of the Summit competence. Therefore, it makes sense to suggest that when the Council is deciding by virtue of the powers delegated to it by the Summit, such decision should be made by consensus as at that time the Council is not acting as the Council but rather as the Summit (in the name and on behalf of the Summit).

57 Art. 11(9) of the Treaty.

$5^{8}$ Art. 12(3) of the Treaty. 